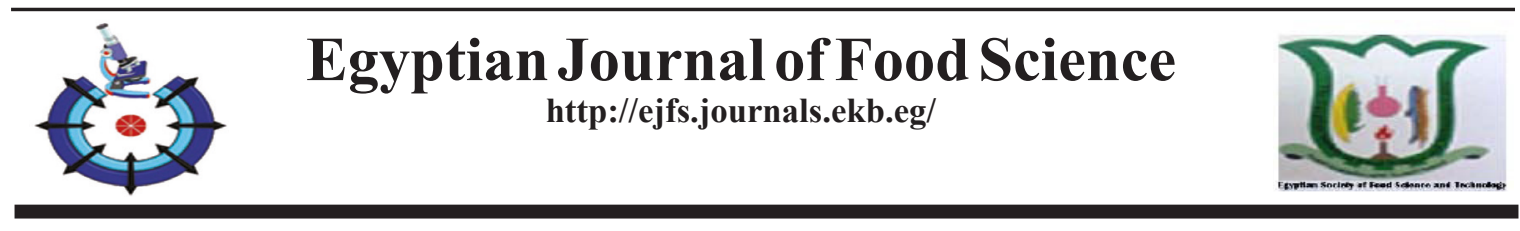

\title{
Quality Characteristics of Gluten-Free Cookies Prepared from Oat and Unripe Banana Flour Blends
}

Hasnaa M. Abo Taleb ${ }^{1 *}$ and Rasha M. Arafa ${ }^{2}$

${ }^{1}$ Department of Horticultural Crops Tech. Res., Food Technology Research Institute, Agricultural Research Center, Giza, Egypt.

${ }^{2}$ Department of Home Economics, Faculty of Specific Education, Damietta University,

Damietta, Egypt.

\begin{abstract}
$\mathbf{T}$ HE present study was carried out to develop quality characteristics of gluten-free cookies prepared from oat and unripe banana flour blends. Oat flour (OF) got substituted with unripe banana flour (UBF) at the levels of 25, 50, 75, and 100\% in terms of the physicochemical and sensory evaluation of cookies. The obtained results revealed that the gross chemical composition showed that of contained moisture $(6.99 \%)$, crude protein $(16.65 \%)$, crudef at $(9.13 \%)$, ash $(1.82 \%)$, crude fiber $(10.87 \%)$, total carbohydrates $(65.33 \%)$, and caloric value $(410.14 \mathrm{kcal} / 100 \mathrm{~g})$. While, $U B F$ contained $6.79,4.80,5.16,2.95,13.03,84.93 \%$, and 363.56 $\mathrm{kcal} / 100 \mathrm{~g}$ for moisture, crude protein, crude fat, ash, crude fiber, total carbohydrates, and caloric value, respectively. It should be noticed that the increase of UBF in cookies led to the increased proportion of ash, crude fiber, total carbohydrate, and the decreased proportion of crude fat, crude protein, and caloric value compared to control. Physical parameters including weight, thickness, diameter, and spread ratio in cookies with $25 \%$ and $50 \%$ UBF didn't differ significantly compared to the control; these ratios recorded the best results. High levels of UBF caused harder cookies. Regarding cookies colors, results observed that the brightness $\left(\mathrm{L}^{*}\right)$ and yellowness values $\left(b^{*}\right)$ in cookies had gradually declined with the increasing levels of UBF, whereas, redness $\left(a^{*}\right)$ value had increased, which means that the UBF resulted in darker cookies when the addition was higher. The total score for overall palatability was acceptable for all cookies, but samples of cookies containing 25 and 50\% UBF had a higher total score than the other samples. In conclusion, the current study confirms that unripe banana flour can be used up to $50 \%$ in the production of a gluten-free diet -such as cookies- with improving the nutritional, sensorial, and physicochemical quality of these products.
\end{abstract}

Keywords: Oat, Unripe banana, Cookies, Gluten-free, Functional food.

\section{Introduction}

Lately, there has been a continuous and consistent ascent in shopper interest inwheat-free foods (Triticum aestivum) to lessen the danger of a problem known as celiac disease. Studies recommended that celiac disease can be treated by dodging the utilization of gluten (Cahyana et al., 2020). In 2007, the Food and Drug Administration (FDA) introduced a labeling requirement for gluten-free foods to fulfill the interest for high-quality gluten-free cookies/ bread with comparable quality with wheat flourdependent on cookies and bread. Accordingly, the "Gluten-free" law is defined as any food containing lower than $20 \mathrm{ppm}$ of gluten (Rai et al., 2014; Bascunan et al., 2017). Oat flour is naturally without gluten, ensuing clinical investigations have demonstrated that utilization of moderate or even large amounts of oat can be endured by most adult celiac patients (Rasane et al., 2015). As a result, without gluten items like pasta, biscuit, and snacks have been created for celiac patients from oats (Ballabio et al., 2011).

\footnotetext{
"Corresponding author: dr.hasnaa_m@yahoo.com

Received :31/12/2020; Accepted :27/5/2021

DOI : 10.21608/EJFS.2021.55588.1088

C2021 National Information and Documentation Centre (NIDOC)
} 
Oat (Avena sativa L.) is interesting among cereals because of its rich nutritious parts and multifunctional attributes. Oats are an excellent source of dietary fiber, especially $\beta$-glucan (Chauha et al., 2018). $\beta$-glucan is a profoundly thick, soluble fiber found; fundamentally, in the endosperm cell mass of the oats. $\beta$-glucan is composed of glucose particles with mixed b-(14) and b-(1-3) bonds, this exceptional substance structure is answerable for physical properties, like viscosity and solubility, just as the ability to influence the metabolism of cholesterol (Butt et al., 2008 and Othman et al., 2011). In addition, the FDA revealed that foods containing $0.75 \mathrm{~g}$ $\beta$-glucan or $1.7 \mathrm{~g}$ soluble fiber per serving may reduce the danger of coronary disease (Choo \& Aziz, 2010). There is also evidence that oat grains and their water-soluble fiber improved fasting, postprandial blood glucose levels, and insulin response in patients with diabetes mellitus (Hou et al., 2015 and Schlozman \& Glei, 2017). Also, it may eliminate constipation; reduce the risk of hypertension, obesity, cardiovascular diseases, and colon cancer (Chen \& Raymond 2008; Arendt \& Dal Bello 2011 and Ekströmet al., (2017). Besides, the majority of people suffering from celiac disease can tolerate oats (Othman et al., 2011). Oat has picked up extensive consideration for its high contents of proteins and its unsaturated fatty acids. Oats also have folates, zinc, iron, selenium, copper, manganese, carotenoids, betaine, choline, just as the vitamin E-like compounds, tocotrienols, and tocopherols (Bocchiet al., 2021). According to Palfi and Knežević (2018) oats give a one-of-a-kind mix of antioxidant compounds which incorporate wax alcohol and acid esters; avenanthramides; and oat saponins, these oat extracts have been appeared to inhibit the arrangement of receptive oxygen species in vitro, which oxidize and advance the atherogenicity of LDL-cholesterol.

Banana is perhaps the most cultivated tropical fruit in the world. Overall, more than a thousand assortments of bananas are delivered. The production of banana assortments relates to around $15 \%$ of the total fresh fruit produced in the world, reaching about 110 million tons of bananas per year (Falcomer et al., 2019). Nonetheless, right around $31 \%$ of all bananas collected is lost because the majority of the population consumes ripe bananas and it is a climate fruit. Ripe bananas are susceptible to mechanical damage and perishable during the ripening process, making their storage and transport difficult (Jiang et al., 2015). Nearly $20 \%$ of banana creation isn't popularized because of size and appearance defects, raising their losses. Along these lines, green banana flour creation has been offered as an answer for high paces of waste among banana crops by the two analysts and authorities of different nations to provide a means of effectively utilizing fruits rejected as unsuitable for sale or export (Cahyana et al., 2020). According to Falcomer et al. (2019), most people are familiar with yellow bananas and consume them regularly for their nutritional profile, but do not usually consume green and unripe bananas due to the typical hardness and their high astringency. Green bananas vary slightly in taste, texture, and composition. Green banana (Musa paradisiaca L.) has plenty of resistant starch (RS), representing over $70 \%$ of the dry weight of the peeled banana fruit (Wang et al., 2017). Resistant starch is a type of starch that can't be digested in the small intestine because of its high degree of crystalline intrinsic structure (Choo \& Aziz 2010 and Zhang et al., 2017). Consequently, it is classified as a type of dietary fiber which is fermented in the large intestine, producing short-chain fatty acids (Bello-Pérez and Agama-Acevedo, 2019). These short-chain fatty acids make the climate of the colon more acidic by bringing down the intestinal $\mathrm{pH}$, thus less desirable for bacteria's growth (Murphy et al., 2008), that helps in treating inflammatory bowel disease, preventing intestinal disease (Wang et al., 2017) which reduces the risk of colorectal cancer (Higgins and Brown 2013) and cardiovascular diseases (Norhidayah et al., 2014), also alleviates constipation (Wang et al., 2014). Green bananas contain high measures of basic minerals, such as potassium, and different vitamins, e.g., A, B1, B2, and C (Choo and Aziz 2010). They are an important source of polyphenols (flavonoids, anthocyanins, tannins) that show antioxidant capacity. The existence of large quantities of bioactive compounds such as flavonoids and carotenoids related to dietary fiber (known as antioxidant dietary fiber) has been important as it is correlated with the anticipation of constant degenerative infections (Bello-Pérez and AgamaAcevedo, 2019). In this context, Zandonadi et al. (2012) indicated that the use of green bananas in the production of gluten-free food could improve the nutritional, sensory, and mechanical quality of these products. On the other hand, De Gouveia and Zandonadi (2013) and Campuzano et al. (2018) proposed that green banana flour be used 
as a functional ingredient for gluten-free bakery products, just as giving more affordable products - at a lower cost - to the general population.

The utilization of accommodation snacks is growing recently, due to hustle and bustle in developing countries' ways of life and financial developments (Abdullah et al., 2016). Cookies have thus become one of the most desirable in these nations, snacks. Cookies may be graded as ready-to-eat and easy foods. Traditionally, the process of making cookies is very straight forward, with basic ingredients consisting of flour, eggs, and sugar. Cookies are commonly known as flat, hard, and crunchy food (Bolarinwa et al., 2019). Considering all that, the aim of the present study is the development of a cookie's formulation containing green banana and oat flour that contribute to the gluten-free cookies production - as a functional food - and evaluate the effect of substituting various amounts of green banana and oat flour on physicochemical and sensory characteristics of the gluten-free cookies.

\section{Materials and Methods}

\section{Materials}

Green bananas of Sindihi CV. (Musa paradisiace L) harvest of 2020 was obtained (about 30kg) from Horticulture Research Institute, El-Kanater El-Khairia, Ministry of Agriculture, Egypt. All ingredients used in the cookies' formulation (oat flour, sugar powder, butter, eggs, vanilla, and baking powder) were commercially available and obtained from the local market from Damietta Governorate, Egypt.

\section{Methods}

Preparation of green banana flour

Fresh green bananas were washed with water and subjected to steaming for $15 \mathrm{~min}$ at $82^{\circ} \mathrm{C}$. Bananas were peeled and cut into pieces for 3 $\mathrm{mm}$ thickness and pre-treated with $0.5 \%(\mathrm{w} / \mathrm{v})$ citric acid solution for $10 \mathrm{~min}$ (To reduce the enzymatic browning) and $1 \%$ Calcium chloride (for preservative and act as firming agent) for $15 \mathrm{~min}$ are used for drying processes. Pieces were dried for $12 \mathrm{hr}$ at $60^{\circ} \mathrm{C}$ in an oven dryer. After drying ground into flour using a grinder, Banana flour was packed into pouches and then stored at room temperature (Sunitha et al., 2017).

\section{Formulation and preparation of cookies}

The cookies were prepared with slight modification by using the AACC method (AACC, 2000). The control and the other experimental formulations are presented in Table 1. In a large mixing bowl, the butter and powder sugar were mixed by an electric mixer on medium speed for 30 s, and then add the beaten eggs and vanilla until mixed. Add flour and baking powder until dough combined. The dough was refrigerated at least for $1 \mathrm{~h}$. The dough was sheeted to a uniform thickness of $5 \mathrm{~mm}$ and cut into circular shapes of $60 \mathrm{~mm}$ diameter. Baking was carried out at $180^{\circ} \mathrm{C}$ for $15 \mathrm{~min}$. Cookie samples were cooled and stored in air-tight containers before physical and chemical evaluation. Cookies were made from oat flour to serve as a control.

TABLE I. Formulation of cookies.

\begin{tabular}{lccccc}
\hline Ingredients (g) & Control & $\mathbf{1}$ & $\mathbf{2}$ & $\mathbf{3}$ & $\mathbf{4}$ \\
\hline Oat flour & 100 & 75 & 50 & 25 & - \\
Green banana flour & - & 25 & 50 & 75 & 100 \\
Butter & 50 & 50 & 50 & 50 & 50 \\
Sugar & 40 & 40 & 40 & 40 & 40 \\
Egg & 30 & 30 & 30 & 30 & 30 \\
Baking powder & 1 & 1 & 1 & 1 & 1 \\
Vanilla & 1 & 1 & 1 & 1 & 1 \\
\hline
\end{tabular}




\section{Gross chemical composition}

Oat, unripe banana flours composition and cookies were analyzed for moisture, ash, crude protein, crude fiber and crude fat contents, while total carbohydrates were calculated by difference according to AOAC (2016). The caloric value was calculated according to the following equation :

$$
\begin{gathered}
\text { Caloric value }=4(\text { protein } \%+\text { carbohydrates } \%) \\
+9(\text { fat } \%)
\end{gathered}
$$

\section{Physical evaluation of cookies}

The physical parameters of three cookies were evaluated in terms of weight, diameter (D), thickness (T), and spread ratio (diameter/ thickness) according to the standard method. After cooling the cookies for $30 \mathrm{~min}$, diameter and thickness measurements were taken using a vernier caliper. Then cookies are put in plastic bags, and kept in a freezer at $-18^{\circ} \mathrm{C}$ for further physical and chemical analysis.

\section{Hardness}

The hardness of the cookies was measured using a Texture Analyzer (Comtech, B type, Taiwan). A test speed of $1 \mathrm{~mm} / \mathrm{s}$ was used for all tests. Three replicates of each formulation were conducted. breaking strength. Cookies were broken using the three-point bending rig probe. the experimental conditions were supports: $50 \mathrm{~mm}$ apart, a $20 \mathrm{~mm}$ probe travel distance. the force at break (N) was measured (Bourne, 2003).

\section{Color analysis}

Color changes of cookies were quantified in the $\mathrm{L}^{*}, \mathrm{a}^{*}, \mathrm{~b}^{*}$ color space. The International Commission on Illumination (CIE) parameters $\mathrm{L}^{*}, \mathrm{a}^{*}$ and $\mathrm{b}^{*}$ were measured with a (Minolta CR 3600, Minolta Camera, Co., Osaka, Japan). The calorimeter was calibrated with a standard white ceramic plate $(\mathrm{L}=95.97, \mathrm{a}=-0.13, \mathrm{~b}=$ $0.30)$ prior to reading. Corresponding $L^{*}$ value (lightness of color from zero (black) to 100 (white); $a^{*}$ value (degree of redness $(0-60)$ or greenness ( 0 to -60$)$; and $b^{*}$ values (yellowness $(0-60)$ or blueness $(0$ to -60$)$ were measured for all the samples.

\section{Sensory analysis}

Sensory evaluation of cookies was done as described by AACC (2000) using 10 panelists of staff members from the Department of Horticultural Crops Tech. Res., Food Technology Research Institute, Agricultural Research Center, Giza, Egypt. Samples of the cookies were prepared one day earlier before the evaluation, cooled for $1-2 \mathrm{hr}$ at room temperature $\left(25 \pm 3^{\circ} \mathrm{C}\right)$.

Egypt. J. Food Sci. 49, No.2 (2021)
Sensory attributes for color, taste, flavor, texture, and overall acceptability were evaluated.

\section{Statistical analysis}

All samples were analyzed in triplicates and the mean values were expressed. Analysis was assessed using the Statistical Analysis Software for Windows (SAS, 2008). The significant difference between the mean values were determined by using the analysis of variance (ANOVA) and Duncan's multiple range test was conducted at a significance level of $p<0.05$. Sensory data scores were analyzed by analysis of variance with mean separation by LSD ( $<<$ $0.05)$.

\section{Results and Discussion}

Gross chemical composition and caloric value of oat and unripe banana flours

The obtained results are presented in Table 2 and it could be observed that Oat flour (OF) contained $6.99,16.65,9.13,1.82,10.87,65.33 \%$, and $410.14 \mathrm{kcal} / 100 \mathrm{~g}$ for moisture,crudeprotein, crudefat, ash, crude fiber, total carbohydrates, and caloric value, respectively. Barbara et al. (2020) indicated that oat flour contained $12.37 \%$ moisture, $13.27 \%$ protein, $1.83 \%$ ash, and $12.9 \%$ dietary fiber. Meanwhile, Youssef et al. (2016) revealed that the chemical composition of oat flours ranged between 9.96 - 10.47\% moisture, $11.61-13.62 \%$ crude protein, $7.23-8.92 \%$ crude fat, $3.535-5.875 \%$, crude fiber, $2-2.15 \%$ ash, and 69.435 - $75.625 \%$ carbohydrates, while the caloric values of oat flours were 412.5 and $414.01 \mathrm{kcal} / 100 \mathrm{~g}$ for both red and common oat. On the other hand, the results in the same Table 2 appeared that unripe banana flour(UBF) contained moisture $(6.79 \%)$, crude protein $(4.80 \%)$, crude fat $(5.16 \%)$, ash $(2.95 \% 0$, crude fiber $(13.03 \%)$, total carbohydrates $(84.93 \%)$ and caloric value $(363.56 \mathrm{kcal} / 100 \mathrm{~g})$. Khalil et al. (2017) found that UBF contained $12.05 \%$ moisture, $4.2 \%$ crude protein, $0.43 \%$ fat, $2.5 \%$ ash, $6.3 \%$ crude fiber, and $86.57 \%$ of total carbohydrates. While, Bezerra et al. (2013) found that protein, fat, ash, fiber, and carbohydrates of UBF were $4.41 \%, 0.45 \%, 1.08 \%, 8.49 \%$, and $86.9 \%$, respectively. Türker et al. (2016) illustrated that UBF is viewed as a reasonable organized item for use in food processing, it has a high fiber, carbohyd rate, and mineral content, appearing, consequently, a high potential as an ingredient in the formulation of several foodstuffs (Bezerra et al., 2013). 
Gross chemical composition and caloric value of cookies with oat and unripe banana flours

Results presented in Table 3 showed the gross chemical composition of control (cookies with oat flour OF) and formulas (cookies with unripe banana flour UBF), it was found that moisture contents of control were less than formulasF1,F2,F3, and higher than F4 (3.69, $4.85,5.80,4,73$ and $3.46 \%$, respectively).From the same Table, it could be observed that ash content was $1.57,1.26,1.63,2.12$, and $2.37 \%$ for control, F1, F2, F3, and F4, respectively. The same Table 3 appeared that, crude protein content of control (19.54\%), F1 (17.88\%), F2 (14.58\%), F3 $(10.14 \%)$, and F4 (9.35\%), while crude fat content of control was higher than treatments F1, F2, F3, and F4 which were 24.95, 21.72, 18.61, 16.38 and $12.55 \%$, respectively. The data in Table 3 showed that crude fiber contents of control were less than formulas F1, F2, F3, and F4 (10.22, 10.90, 11.01, 11.66 , and $12.58 \%$, respectively). Meanwhile, the content of total carbohydrates in control and cookies formulas were 50.23, 54.29, 59.36, 66.61 , and $72.24 \%$ for control, F1, F2, F3, and F4, respectively. On the other hand, the caloric value of control was $503.70 \mathrm{kcal} / 100 \mathrm{~g}$ while it ranged from 439.42 to $484.16 \mathrm{kcal} / 100 \mathrm{~g}$ in different cookies for mulas. Concerning the previous results, it should be noticed that the increase of UBF in cookies led the increased proportion of ash, crude fiber, total carbohydrate, and the decreased proportion of crude fat, crude protein, and caloric value compared to control. Bezerra et al. (2013) reported that the crude fiber content in the cookies increased due to the greater amount of fiber provided by the green banana flour.

TABLE 2. Gross chemical composition and caloric value of oat and unripe banana flours (\% On dry weight basis).

\begin{tabular}{lcc}
\hline Components & OF & UBF \\
\hline Moisture content & $6.99 \pm .12$ & $6.79 \pm .11$ \\
Crude protein & $16.65 \pm .14$ & $4.80 \pm .09$ \\
Crude fat & $9.13 \pm .31$ & $5.16 \pm .025$ \\
Ash & $1.82 \pm .18$ & $2.95 \pm .14$ \\
Crude fiber & $10.87 \pm .17$ & $13.03 \pm .25$ \\
Total carbohydrates* & $65.33 \pm .40$ & $84.93 \pm .17$ \\
caloric Value (Kcal) & $410.14 \pm 2.15$ & $363.56 \pm .96$ \\
\hline
\end{tabular}

Each value represents the mean \pm SD. OF: oat flour. UBF: unripe banana flour

* Total carbohydrates were calculated by differences .

TABLE 3. Gross chemical composition and caloric value of cookies with oat and unripe banana flours (\% Ondry weight basis).

\begin{tabular}{lccccc}
\hline \multirow{2}{*}{ Components(\%) } & \multirow{2}{*}{$\begin{array}{c}\text { Control } \\
\text { cookies (OF) }\end{array}$} & \multicolumn{5}{c}{ Formulas cookies with UBF } \\
\cline { 3 - 6 } & $3.69 \pm .29$ & $4.85 \pm .23$ & $5.80 \pm .21$ & $4.73 \pm .19$ & $3.46 \pm .21$ \\
\hline Moisture content & $1.57 \pm .17$ & $1.26 \pm .05$ & $1.63 \pm .08$ & $2.12 \pm .05$ & $2.37 \pm .06$ \\
Ash & $19.54 \pm .23$ & $17.88 \pm .17$ & $14.58 \pm .37$ & $10.14 \pm .16$ & $9.35 \pm .22$ \\
Crudeprotein & $24.95 \pm .05$ & $21.72 \pm .55$ & $18.61 \pm .38$ & $16.38 \pm .31$ & $12.55 \pm .12$ \\
Crudefat & $10.22 \pm .19$ & $10.90 \pm .14$ & $11.01 \pm .13$ & $11.66 \pm .40$ & $12.58 \pm .36$ \\
Crude fiber & $50.23 \pm .41$ & $54.29 \pm .87$ & $59.36 \pm .36$ & $66.61 \pm .37$ & $72.24 \pm .25$ \\
Total carbohydrates* & $503.70 \pm .49$ & $484.16 \pm 2.07$ & $463.29 \pm 1.48$ & $454.50 \pm 2.22$ & $439.42 \pm 1.22$ \\
\hline
\end{tabular}

Each value represents the mean \pm SD.* Total carbohydrates were calculated by differences

$\mathrm{OF}$ : oat flour. UBF: unripe banana flour.Control: $100 \% \mathrm{OF}$. F1: $25 \% \mathrm{UBF}+75 \% \mathrm{OF}$.

F2: $50 \% \mathrm{UBF}+50 \% \mathrm{OF}$. F3: $75 \% \mathrm{UBF}+25 \% \mathrm{OF}$. F $4: 100 \% \mathrm{UBF}$ 
Physical properties of cookies with oat and unripe banana flours

The results of weight $(\mathrm{g})$, thickness $(\mathrm{mm})$, diameter $(\mathrm{mm})$, spread ratio, and hardness $(\mathrm{N})$ of cookies with oat and unripe banana flours could be seen in Table 4. There were no significant $(\mathrm{P} \leq 0.05)$ differences between the values obtained for the weight $(\mathrm{g})$, thickness $(\mathrm{mm})$, and diameter $(\mathrm{mm})$ of cookies supplemented with 25 and $50 \%$ UBF and the control (100\% oat flour) cookies. However, these parameters decreased significantly in the case of cookies supplemented with more than 50\% UBF. Moreover, the spread ratio in cookies with $25 \%$ and $50 \%$ UBF didn't differ significantly as compared to the control. While, spread ratio in cookies with $75 \%$ and $100 \%$ of UBF was higher than the control. These results were consistent with Hassan (2002) who found that the addition of resistant starches by $50 \%$ to wheat flour led to cookies with high spread ratio and low thickness than control.

On the other hand, hardness values $(\mathrm{N})$ for all formulas had increased gradually with the increasing amount of UBF added to be 14.99, 17.16, and 17.67 as compared to the control, except the formula containing $25 \%$ of UBF that showed no significant differences with the control. That means blends containing more than $50 \%$ of UBF produced a harder cookie that required more force to compress. In the present study increa se in hardness may be due to a higher amount of fiber in the UBF. The results are in line with Sandhu et al. (2018) who confirmed that with the increase in the level of oatmeal flour from 0 to $30 \%$ in cookies, a significant increase in cookies hardness was observed; this may be due to a higher amount of fiber in the oatmeal. Also, similar results were reported by Singh et al. (2008) which indicated that a significant increase in dough hardness was observed due to an increase in fiber content after the addition of sweet potato flour.

Color plays an important role in consumer's acceptability of the product. Table 5 showed the color attributes of cookies with oat flour (OF) and unripe banana flour (UBF). The color of cookies was assessed in terms of lightness $\left(\mathrm{L}^{*}\right)$, redness $\left(a^{*}\right)$, and yellowness $\left(b^{*}\right)$. The cookies containing UBF had significantly lower $\mathrm{L}^{*}$ values (54.69-50.35) than the control (57.79). The lowest $\mathrm{L}^{*}$ value was observed in $100 \%$ UBF cookies. This was attributed to a Mail lard reaction causing browning during baking at high temperatures. On the other hand, the $\mathrm{a}^{*}$ values are indicative of the red or green color (positive value indicates red and negative value indicates green). The results in the same Table 5 revealed that all cookies were in redness (positive $\mathrm{a}^{*}$ ). But the cookies treated with UBF were significantly different with control (OMF) for $\mathrm{a}^{*}$ value, redness of formulas cookies showed a slight increase from lowest value (4.55) observed in $25 \% \mathrm{UBF}$ to highest value (5.25) found in $100 \%$ UBF.The $b^{*}$ color value indicates the yellow or blue colors (a positive value indicates yellow and a negative value indicates blue). The data indicated that the substitution of oat flour for $\operatorname{UBF}(25,50,75$, and $100 \%$ ) resulted in significantly lowered $b^{*}$

TABLE 4. Physical properties of cookies with oat and unripe banana flours.

\begin{tabular}{lccccc}
\hline \multirow{2}{*}{ Parameters } & \multirow{2}{*}{$\begin{array}{c}\text { Control } \\
\text { cookies (OF) }\end{array}$} & \multicolumn{4}{c}{ Formulas cookies with UBF (\%) } \\
\cline { 3 - 6 } & $19.04 \pm 0.11^{\mathrm{a}}$ & $18.82 \pm 0.13^{\mathrm{a}}$ & $18.70 \pm 0.20^{\mathrm{ab}}$ & $18.38 \pm 0.32^{\mathrm{b}}$ & $17.54 \pm 0.39^{\mathrm{c}}$ \\
\hline Weight (g) & $7.22 \pm 0.08^{\mathrm{a}}$ & $7.14 \pm 0.16^{\mathrm{a}}$ & $6.96 \pm 0.20^{\mathrm{a}}$ & $6.28 \pm 0.43^{\mathrm{b}}$ & $5.92 \pm 0.21^{\mathrm{c}}$ \\
Thickness (mm) & $66.20 \pm 0.83^{\mathrm{a}}$ & $63.80 \pm 2.58^{\mathrm{ab}}$ & $61.40 \pm 2.07^{\mathrm{bc}}$ & $59.60 \pm 2.40^{\mathrm{cd}}$ & $57.80 \pm 2.38^{\mathrm{d}}$ \\
Diameter (mm) & $9.16 \pm 0.16^{\mathrm{b}}$ & $8.93 \pm 0.43^{\mathrm{b}}$ & $8.82 \pm 0.33^{\mathrm{b}}$ & $9.49 \pm 1.00^{\mathrm{a}}$ & $9.76 \pm 0.86^{\mathrm{a}}$ \\
Spread ratio & $10.99 \pm 1.30^{\mathrm{c}}$ & $13.44 \pm 1.54^{\mathrm{bc}}$ & $14.99 \pm 2.05^{\mathrm{ab}}$ & $17.16 \pm 1.48^{\mathrm{a}}$ & $17.67 \pm 1.88^{\mathrm{a}}$ \\
\hline
\end{tabular}

Mean values in the same row which are not followed by the same letter are significantly different $(\mathrm{p} \leq 0.05)$.

OF: Oat flour. UBF: unripe banana flour. Control: 100\% OF. F1: $25 \% \mathrm{UBF}+75 \% \mathrm{OF}$. F2: $50 \% \mathrm{UBF}+50 \% \mathrm{OF}$. F3: $75 \% \mathrm{UBF}+25 \% \mathrm{OF}$ F4: $100 \%$ UBF. 
values $(15.30-12.40)$ from the control (17.02). The yellowness of composite treats diminishes might be because of the debasement of precarious yellow compounds during baking. The difference in cookies color can be credited to the pigmentation of flours, which will rely upon the plant source, extraction technique, molecule size, and the drying time/temperature relationship. As is notable, the flour tone is frequently impacted by its polyphenolic content. Regarding the previous results, it could be observed that the brightness $\left(\mathrm{L}^{*}\right)$ and yellowness values $\left(\mathrm{b}^{*}\right)$ in cookies had gradually declined with the increasing levels of UBF, whereas, redness ( $\left.a^{*}\right)$ value had increased, which means that the UBF resulted in darker cookies when the addition was higher.

Sensory characteristics of cookies with oat and unripe banana flours

Table 6 presented the sensory characteristics of prepared cookies with oat and unripe banana flours. The data showed that most formulations were acceptable in all sensory evaluation attributes (color, taste, flavor, texture, and overall palatability) and no significant variations $(\mathrm{P}<0.05)$ between the formulas supplemented with 25 and $50 \%$ of cookies with OMF and UBF when compared with control. Whereas substitution with high levels from UBF by 75 and 100\% caused a significant difference $(\mathrm{P}<0.05)$ in the same sensory evaluation attributes as compared to the control. Although results observed that cookies containing 100\% UBF had the highest hardness score that led to a reduction in overall palatability, but the results of the acceptance test showed that consumers like most of the formulas.
The total score for overall palatability ranged from 7.40 to 9.25 , it should be noticed that formulas of cookies containing 25 and 50\% UBF had a higher total score for overall palatability than the other formulas. Generally, it means that the mixture of oat and unripe banana flours can be used in the preparation of cookies. These results align with Păucean et al., (2015) who found that sensory evaluation showed that rice flour substitution with high levels from quinoa flour led to a steady decrease in the sensory scores for overall acceptability. In another study; Zafar \& Tusneem Kausar (2019) showed that sensory evaluation of cookies demonstrated that supplementation of guava flour improves all sensorial parameters. Ishartati et al. (2019) indicated that the most preferred product by panelists is the level of substitution of Mamaliga apple flour 25\% and $30 \%$. Also, Al-Lami et al. (2020) showed that sensory evaluation was best when mixed quinoa and rice by $50: 50$, which was characterized by acceptable characteristics.

The costing of cookies with oat and unripe banana flours

Table 7 shows the cost of cookies with oat and unripe banana flours. After adding 30\% of energy and labor consumption, as well as $10 \%$ of packing and packaging to each formula, the results showed that F4 had the lower cost (42.81 pounds) followed by F3, F2, and F1 (45.93, 49.05, and 52.18 pounds) respectively, while the control had the highest cost (55.30 pounds). Results appeared that by increasing the percentage of the addition of green banana flour, the final cost of the product decreases compared to the control.

TABLE 5. Color attributes of cookies with oat and unripe banana flours.

\begin{tabular}{|c|c|c|c|c|c|}
\hline \multirow{2}{*}{ Attributes } & \multirow{2}{*}{$\begin{array}{c}\text { Control } \\
\text { cookies (OF) }\end{array}$} & \multicolumn{4}{|c|}{ Formulas cookies with UBF } \\
\hline & & F1 & F2 & F3 & F4 \\
\hline $\mathbf{L}^{*}$ & $57.79 \pm 0.24^{\mathrm{a}}$ & $54.69 \pm 0.14^{b}$ & $52.72 \pm 0.17^{\mathrm{c}}$ & $51.89 \pm 0.31^{\mathrm{d}}$ & $50.35 \pm 0.25^{\mathrm{e}}$ \\
\hline $\mathbf{a}^{*}$ & $4.17 \pm 0.12^{\mathrm{e}}$ & $4.55 \pm 0.15^{\mathrm{d}}$ & $4.70 \pm 0.70^{\mathrm{c}}$ & $5.17 \pm 0.51^{\mathrm{b}}$ & $5.25 \pm 0.14^{\mathrm{a}}$ \\
\hline $\mathbf{b}^{*}$ & $17.02 \pm 0.11^{\mathrm{a}}$ & $15.30 \pm 0.20^{\mathrm{b}}$ & $13.65 \pm 0.25^{\mathrm{c}}$ & $13.73 \pm 0.47^{\mathrm{c}}$ & $12.40 \pm 0.10^{\mathrm{d}}$ \\
\hline
\end{tabular}

Mean values in the same row which are not followed by the same letter are significantly different $(\mathrm{p} \leq 0.05)$.

OF: oat flour. UBF: unripe banana flour. Control: $100 \%$ OF. F1: $25 \% \mathrm{UBF}+75 \% \mathrm{OF}$. F2: $50 \% \mathrm{UBF}+50 \% \mathrm{OF}$. F3: $75 \% \mathrm{UBF}+25 \% \mathrm{OF}$. F4: $100 \% \mathrm{UBF}$ 
TABLE 6. Sensory characteristics of cookies with oat and unripe banana flours.

\begin{tabular}{lccccc}
\hline & \multirow{2}{*}{$\begin{array}{c}\text { Control } \\
\text { Cookies }\end{array}$} & \multicolumn{3}{c}{ Formulas cookies with UBF } \\
\cline { 3 - 6 } & $(\mathbf{O F})$ & $\mathbf{F 1}$ & $\mathbf{F 2}$ & $\mathbf{F 3}$ & F4 \\
\hline Color & $9.35 \pm 0.58^{\mathrm{a}}$ & $9.10 \pm 0.5^{\mathrm{a}}$ & $8.10 \pm 0.3^{\mathrm{b}}$ & $7.50 \pm 0.7^{\mathrm{c}}$ & $6.50 \pm 0.8^{\mathrm{d}}$ \\
Taste & $8.85 \pm 1.00^{\mathrm{a}}$ & $8.85 \pm 0.9^{\mathrm{a}}$ & $8.85 \pm 0.3^{\mathrm{a}}$ & $7.95 \pm 0.9^{\mathrm{b}}$ & $7.55 \pm 0.6^{\mathrm{b}}$ \\
Flavor & $9.00 \pm 1.15^{\mathrm{a}}$ & $8.90 \pm 0.5^{\mathrm{a}}$ & $8.85 \pm 0.5^{\mathrm{a}}$ & $8.35 \pm 0.8^{\mathrm{ab}}$ & $8.00 \pm 0.9^{\mathrm{b}}$ \\
Texture & $9.30 \pm 0.82^{\mathrm{a}}$ & $9.00 \pm 0.6^{\mathrm{a}}$ & $8.70 \pm 0.7^{\mathrm{a}}$ & $7.90 \pm 0.9^{\mathrm{b}}$ & $7.60 \pm 1.0^{\mathrm{b}}$ \\
Overall palatability & $9.10 \pm 0.70^{\mathrm{a}}$ & $9.25 \pm 0.5^{\mathrm{a}}$ & $8.90 \pm 0.6^{\mathrm{a}}$ & $7.95 \pm 0.7^{\mathrm{b}}$ & $7.40 \pm 0.8^{\mathrm{b}}$ \\
\hline
\end{tabular}

Mean values in the same row which are not followed by the same letter are significantly different $(\mathrm{p} \leq 0.05)$.

OF: Oat flour. UBF: unripe banana flour. Control: $100 \%$ OF. F1: $25 \% \mathrm{UBF}+75 \% \mathrm{OF} . \mathrm{F} 2: 50 \% \mathrm{UBF}+50 \% \mathrm{OF}$.

F3: $75 \% \mathrm{UBF}+25 \%$ OF. F4: $100 \% \mathrm{UBF}$

TABLE 7. The costing of cookies with oatmeal and unripe banana flour.

\begin{tabular}{ccccc}
\hline Ingredients & $\begin{array}{c}\text { Weight } \\
(\mathbf{g})\end{array}$ & $\begin{array}{c}\text { Cost } \\
(\mathbf{L E})\end{array}$ & $\begin{array}{c}\text { Formula } \\
\text { No. }\end{array}$ & $\begin{array}{c}\text { Cost of final } \\
\text { product(LE) }\end{array}$ \\
\hline & & & Control & 55.30 \\
OF & 600 & 19.20 & & \\
UBF & 600 & 10.28 & F1 & 52.18 \\
Butter & 300 & 14.40 & & \\
Sugar & 240 & 2.40 & $\mathbf{F 2}$ & 49.05 \\
Egg & 105 & 2.50 & & \\
Baking powder & 1 & 1 & $\mathbf{F 3}$ & 45.93 \\
Vanilla & 0.5 & 0.50 & & \\
& & & $\mathbf{F 4}$ & 42.81 \\
\hline
\end{tabular}

OF: oatmeal flour. UBF: unripe banana flour. Control: $100 \%$ OF. F1: $25 \%$ UBF $+75 \%$ OF. F2: $50 \%$ UBF $+50 \%$ OF. F3: $75 \%$ UBF $+25 \%$ OF. F $4: 100 \%$ UBF

\section{Conclusion}

The current study confirms that unripe banana flour can be used up to $50 \%$ in combination with other cereals to produce a gluten-free product such as cookies. This strategy might be improving the sensorial and physicochemical quality of these products. In addition to ameliorating the nutritional status of people experiencing degenerative illnesses related to the present changing ways of life and climate.

\section{References}

AACC (2000) Approved Methods of the American Association of Cereal Chemists. Published by American Association of Cereal Chemists, Ins. St. Paul, Minnesota, U.S.A.

Egypt. J. Food Sci. 49, No.2 (2021)
Abdullah, N.F., Teo, P.S. and Foo, L.H. (2016) Ethnic differences in the food intake patterns and its associated factors of adolescents in Kelantan. Malaysia, Nutrients, 8 (9), 551-564. https://doi. org/10.3390/nu8090551

Al-Lami, R.H., Mohammed, R.S. and Muhsen, R.H. (2020) Determination of the physical, chemical and sensory properties of gluten-free biscuits by mixing different proportions of anbar rice flour and quinoa flour. Syrian Journal of Agricultural Research, 7 (1), 158-168.http://agri-researchjournal.net/SjarEn/?p=2395

AOAC (2016) Official Methods of Food Analysis. Association of Official Analytical Chemists, Washington, DC, USA, 20th edition. 
Arendt, E. and Dal Bello, F. (2011) Gluten-free cereal products and beverages. Elsevier.

Ballabio, C., Uberti, F., Manferdelli, S., Vacca, E., Boggini, G., Redaelli, R., Catassi, C., Lionetti, E., Penas, E.,and Restani, P. (2011) Molecular characterization of 36 oat varieties and in vitro assessment of their suitability for celiac's diet. Journal Cereal Sciences, 54,110-115.https://doi. org/10.1016/j.jcs.2011.04.004

Barbara, K-M., Renata, T-S. and Joanna, K. (2020) The effect of adding oat flour on the nutritional and sensory quality of wheat bread. British Food Journal, 122(7), 2329-2339. https://doi. org/10.1108/BFJ-07-2019-0493

Bascunan, K. A., Vespa, M. C. and Araya, M. (2017). Celiac disease: understanding the gluten-free diet. European Journal of Nutrition, 56(2), 449459. DOI 10.1007/s00394-016-1238-5. https://doi. org/10.1007/s00394-016-1238-5

Bello-Pérez, L. A. and Agama-Acevedo, E. (2019) Flour and Breads and Their Fortification in Health and Disease Prevention. Banana and mango flours. Academic Press, 153-164.https:// doi.org/10.1016/B978-0-12-814639-2.00012-5.

Bezerra, C.V., Amante, E.R., de Oliveira, D.C., Rodrigues, A.M.C. and da Silva, L.H.M. (2013) Green banana (Musa calendrical) flour obtained in spouted bed - Effect of drying on physio-chemical, functional and morphological characteristics of the starch. Industrial Crops and Products, 41, 241249.https://doi.org/10.1016/j.indcrop.2012.04.035

Bocchi, S., Rocchetti, G., Elli, M., Lucini, L., Lim, C. Y., and Morelli, L. (2021) The combined effect of fermentation of lactic acid bacteria and in vitro digestion on metabolomic and oligosaccharide profile of oat beverage. Food Research International, 142, 110216.https://doi 10.1016/j. foodres.2021.110216

Bolarinwa, I. F., Lim, P. T. and Muhammad, K. (2019) Quality of gluten-free cookies from germinated brown rice flour. Food Research, 3 (3), 199-207. https://doi.org/10.26656/fr.2017.3(3).228

Bourne, M.C. (2003): Food texture and viscosity: concept measurement. Elsevier press, New York / London.

Butt, M. S., Tahir-Nadeem, M., Khan, M. K. I., Shabir, R. and Butt, M. S. (2008) Oat: unique among the cereals. European Journal of Nutrition, 47 (2), 6879. https://doi.org/10.1007/s00394-008-0698-7
Cahyana, Y., Rangkuti, A., Siti Halimah, T., Marta, H., and Yuliana, T. (2020) Application of heatmoisture-treated banana flour as composite material in hard biscuit. CyTA-Journal of Food, 18 (1), 599-605. https://doi.10.1080/19476337.2020. 1805514

Campuzano, A., Rosell, C. M. and Cornejo, F. (2018) Physicochemical and nutritional characteristics of banana flour during ripening. Food Chemistry, 256, 11-17. https://doi.org/10.1016/j. foodchem.2018.02.113

Chauha, N. D., Kumar, K., Kumar, S. and Kumar, H. (2018) Effect of incorporation of oat flour on nutritional and organoleptic characteristics of bread and noodles. Current Research in Nutrition and Food Science Journal, 6 (1), 148-156. http:// dx.doi.org/10.12944/CRNFSJ.6.1.17

Chen, J. and Raymond, K. (2008) Beta-glucans in the treatment of diabetes and associated cardiovascular risks. Vascular Health and Risk Management, 4 (6), 1265-1272. https://doi.org/10.2147/vhrm. s3803

Choo, C. L. and Aziz, N. A. A. (2010) Effects of banana flour and $\beta$-glucan on the nutritional and sensory evaluation of noodles. Food Chemistry, 119(1), 34-40.https://doi.org/10.1016/j. foodchem.2009.05.004

Cunha, C. R. D., Santos, S. L. D., Maciel, V. T., Souza, M. L. D., Furtado, C. D. M. and Carvalho, A. V. (2014) Stability of porridge pre-mixture made with Brazil nut flour and green banana flour with and without milk powder. Food Science and Technology, 34 (3), 585-590.https://doi. org/10.1590/1678-457x.6368

De Gouveia, P. F. and Zandonadi, R. P. (2013) Green banana: new alternative for gluten-free products. Argo Food Industry Hi-Technology, 24 (3), 49-52.

Ekström, L. M., Bok, E. A. H., Sjöö, M. E., and Östman, E. M. (2017). Oat D-glucan containing bread increases the glycaemic profile. Journal of Functional Foods, 32, 106-111. https://doi. org/10.1016/j.jff.2017.02.027

Falcomer, A. L., Riquette, R. F. R., de Lima, B. R., Ginani, V. C. and Zandonadi, R. P. (2019) Health benefits of green banana consumption: A systematic review. Nutrients, 11(6), 1222. https:// doi.org/10.3390/nu11061222

Hassan, M.H.H., (2002) Biochemical studies on some Egyptian foods, M.Sc. Thesis, Faculty

Egypt. J. Food Sci. 49, No.2 (2021) 
of Agricultural, Chemistry Department, Cairo University, Cairo-Egypt.

Higgins, J. A. and Brown, I. L. (2013) Resistant starch: a promising dietary agent for the prevention/treatment of inflammatory bowel disease and bowel cancer. Current Opinion in Gastroenterology, 29 (2), 190-194.https:// doi:10.1097/MOG.0b013e32835b9aa3

Hou, Q., Li, Y., Li, L., Cheng, G., Sun, X., Li, S. and Tian, H. (2015) The metabolic effects of oats intake in patients with type 2 diabetes: a systematic review and meta-analysis. Nutrients, 7(12), 1036910387. https://doi.org/10.3390/nu7125536

Ishartati, E., Sukardi, S., Roeswitawati, D., Zakia, A., and Ulfah, U. (2019) The study of Apple flour formulation for functional cookies. In: IOP Conference Series. Earth and Environmental Science, 379 (1).doi:10.1088/17551315/379/1/012012

Jiang, H., Zhang, Y., Hong, Y., Bi, Y., Gu, Z. and Cheng, L (2015). Digestibility and changes to structural characteristics of green banana starch during in vitro digestion. Food Hydrocolloids, 49, 192-199. https://doi.org/10.1016/j.foodhyd.2015.03.023

Khalil, M. M., Tabikha, M. M., Hosny, M. H. and Kortam, A. A. (2017) Physiochemical and sensory evolution of some bakery products supplemented with unripe banana flour as a source of resistant starch. Journal of Food and Dairy Sciences, 8 (10), 411-417.DOI: 10.21608/JFDS.2017.38925

Murphy, M.M., Douglass, J.S. and Birkett, A. (2008) Resistant starch intakes in the United States. Journal of the American Dietetic Association,108, 67-78.https://doi.org/10.1016/j.jada.2007.10.012

Norhidayah, M., Noorlaila, A. and Nur Fatin Izzati, A. (2014) Textural and sensorial properties of cookies prepared by partial substitution of wheat flour with unripe banana (Musa x paradisiaca var. Tanduk and Musa acuminata var. Emas) flour. International Food Research Journal, 21(6):2133-2139.https:// www. researchgate.net/publication/287311357

Othman, R. A., Moghadasian, M. H. and Jones, P. J. (2011) Cholesterol-lowering effects of oat $\beta$-glucan. Nutrition Reviews, 69 (6), 299309.DOI: 10.1111/j.1753-4887.2011.00401.x

Palfi, M. and Kneževī, N. (2018) Positive effects of oats on human health. In: Proceedings of the $9^{\text {th }}$ International Congress, Flour-Bread, $11^{\text {th }}$ Croatian Congress of Cereal Technologists"
Brašno-Kruh'17”, Opatija, Croatia, 25-27 October 2017 (pp. 151-159). Faculty of Food Technology Osijek, Josip Juraj Strossmayer University.https://www.cabdirect.org/ globalhealth/abstract/20193371680

Păucean, A., Man, S., Muste, S. and Pop, A. (2015) Effect of quinoa flour addition on quality characteristics of rice gluten-free cookies. Journal of Agroalimentary Processes and Technologies, 21(4), 371-378.DOI: 10.21608/ JFDS.2018.77774

Rai, S., Kaur, A. and Singh, B. (2014) Quality characteristics of gluten free cookies prepared from different flour combinations. Journal of Food Science and Technology, 51(4), 785789. DOI: $10.1007 / \mathrm{s} 13197-011-0547-1$

Rasane, P., Jha, A., Sabikhi, L., Kumar, A. and Unnikrishnan, V. S. (2015)Nutritional advantages of oats and opportunities for its processing as value added foods-a review. Journal of Food Science and Technology, 52 (2), 662-675.DOI: 10.1007/ s13197-013-1072-1

Sandhu, R. S., Kamboj, R., and Singh, B. (2018) Textural, color and sensory attributes of high fiber cookies supplemented with oatmeal flour. In IJCA: Proceedings on International Conference on Advanced Engineering and Technology, 4, 21-24.

Schlörmann, W. and Glei, M. (2017) Potential health benefits of $\beta$-glucan from barley and oat. Ernahrungs Umschau 64 (10): 145-149

Singh, S., Riar, C. S. and Saxena, D. C. (2008) Effect of incorporating sweet potato flour to wheat flour on the quality characteristics of cookies, African Journal of Food Science, 2, 65-72. https://www. researchgate.net/publication/228860242

Sunitha, V. B., Krishnaveni, R., Lavanya, A. and Vyshnavi, T. (2017) Study on effect of quality of green banana flour using different drying techniques. The Pharma Innovation Journal, 6 (10) ,01-07.https://www.thepharmajournal.com/ archives/2017/vol6issue10/PartA/6-9-71-308.pdf

Türker, B., Savlak, N. and KaDikci, M.B. (2016) Effect of green banana peel flour substitution on physical characteristics of gluten-free cakes, Current Research in Nutrition and Food Science Journal,4, 197-204. http://dx.doi.org/10.12944/ CRNFSJ.4.Special-Issue-October.25

Wang, J., Huang, H. H. and Chen, P. S. (2017) Structural and physicochemical properties of banana resistant

Egypt. J. Food Sci. 49, No.2 (2021) 
starch from four cultivars. International Journal of Food Properties, 20 (6), 1338-1347.https://doi.org $/ 10.1080 / 10942912.2016 .1209517$

Wang, J., Huang, J. H., Cheng, Y. F. and Yang, G. M. (2014) Banana resistant starch and its effects on constipation model mice. Journal of Medicinal Food, 17 (8), 902-907.doi: 10.1089/jmf.2013.3016

Youssef, M. K. E., Nassar, A.G., EL-Fishawy, F. A. and Mostafa, M. A.(2016)Assessment of proximate chemical composition and nutritional status of wheat biscuits fortified with oat powder. Assiut Journal Agricultural Science, 47 (5), 83-94. DOI: 10.21608/AJAS.2016.2071

Zafar, M. A., and Tusneem Kausar, S. M. (2019) Formulation and physicochemical and sensorial evaluation of biscuits supplemented with guava powder. Pure and Applied Biology, 8 (2), 15881591.https://thepab.org/index.php/journal/article/ view/933

Zandonadi, R. P., Botelho, R. B. A., Gandolfi, L., Ginani, J. S., Montenegro, F. M. and Pratesi, R. (2012) Green banana pasta: an alternative for gluten-free diets. Journal of the Academy of Nutrition and Dietetics, 112 (7), 1068-1072. https://doi.org/10.1016/j.jand.2012.04.002

Zhang, Bi, Y., Jiang, Y., Hong, H., Cheng, Y.and Gu, Z. (2017) Molecular structure and digestibility of banana flour and starch. Food Hydrocolloids, 72, 219-227. https://doi.org/10.1016/j.foodhyd.2017.06.003 


\title{
خصائص جودة الكوكيز خالي الجلوتين المحضر من خليط دقيق الثوفان والموز غير الناضج

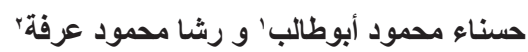

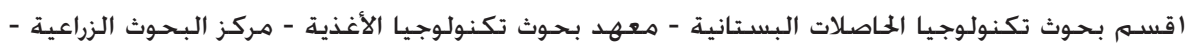

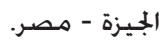 \\ أقسـم الاقتصاد المنزلي ـ كلية التربية النوعية ـ جامعة دمياط ـ مصر.
}

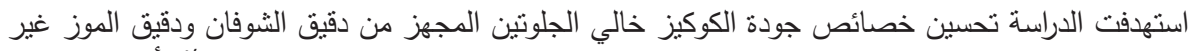

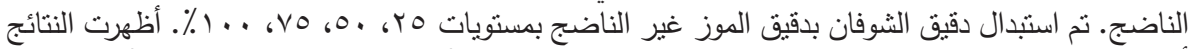

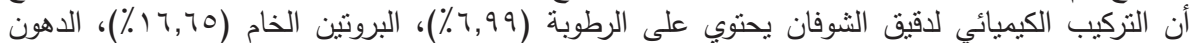

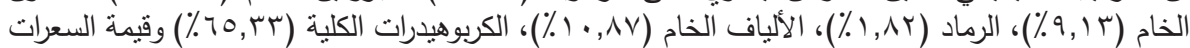

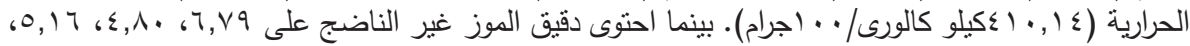

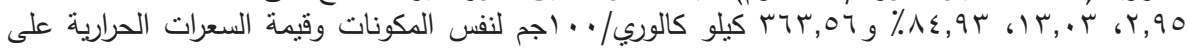

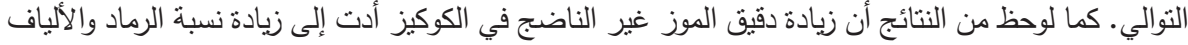

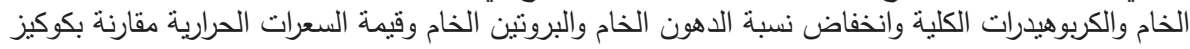

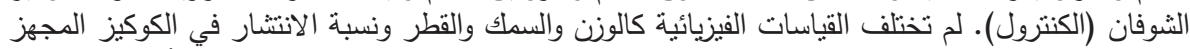

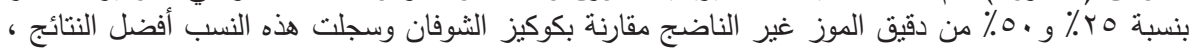

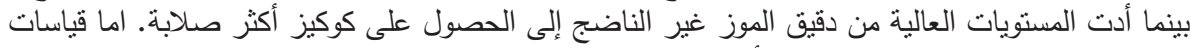

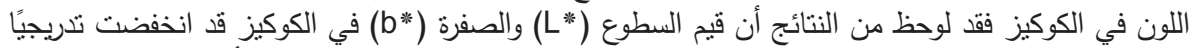

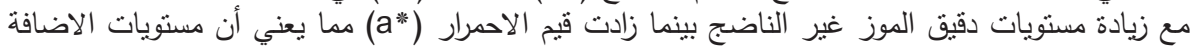

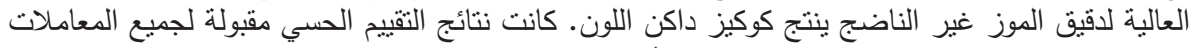

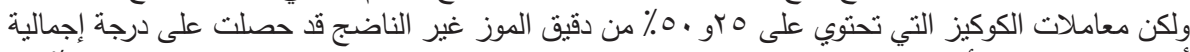

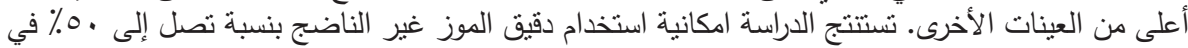
إنتاج منتج غذائي خالي من الجلوتين مع مراعاة الجودة الغذائية والحسية والفيزية الفيزيائية للمنتجات. الكلمات المفتاحية: الشـوفان - الموز غير الناضج - كوكيز - خالي من الجلوتين - أغذية وظيفية.
\end{abstract}

